\title{
MORPHOTECTONIC ANALYSIS OF SOUTHERN ARGOLIS PENINSULA (GREECE) BASED ON GROUND AND SATELLITE DATA BY GIS DEVELOPMENT
}

\author{
Vassilopoulou S. \\ National and Kapodistrian University of Athens, Faculty of Geology \& Geoenvironment, \\ Department of Geophysics-Geothermics, 15784 Athens, Greece, vassilopoulou@geol.uoa.gr
}

\begin{abstract}
Southern Argolis Peninsula is an interesting Geological and Geomorphological area due to the variety of the geological structures and the interchange on the terrain. Ground and remote sensing data, relating to geology and tectonics, were compiled with terrain analysis data in a GIS data base, in order to perform morpho-tectonic analysis in the Southern Argolis Peninsula. Terrain analysis data were automatically produced by the specific software "PROANA" (based on ArcGIS). The main direction of Southern Argolis Terrain is E-W. The same direction is observed from the rose-diagrams of morphological discontinuities. The hydrographic network has a NW-SE main direction. The depositional planation surfaces (0-5\%) that are located near the coast are related with neotectonic faults. The direction of the Faulting Zones is mainly ESE-WNW and E-W. The most active tectonic structures were observed to the southern and south-western area of Southern Argolis Peninsula, towards Kranidi and Argolikos Gulf.
\end{abstract}

Key words: morpho-tectonic analysis, terrain analysis, GIS, remote sensing data, image processing, image interpretation, Argolis Peninsula, Greece.

\section{Introduction}

The morpho-tectonic analysis of Southern Argolis Peninsula (SE Peloponnesus) is the subject of the present research. The variety of the geological structures (Alpine, Post-Alpine and Volcanic formations), as well as the interchange on the terrain (mountains, hills, plains, valleys, morphological discontinuities), are the main reasons that Southern Argolis has great interest not only from the Geological, but also from the Geomorphological point of view.

The linear structures (morphological and tectonic) have not a consistent direction. Different directions are observed in the different parts of the area: Region of Didyma - Iria, Adheres, Kranidi Ermioni, Porto-Cheli, Poros Island, Methana Peninsula (Fig. 1c). Each region is characterized by different formations and has its own tectonic structure. Terrain's morphological peculiarities, among others, basically depend on tectonic phenomena and geological formations. From attentive study of the terrain, interesting results can be extracted concerning the tectonic - neotectonic - morpho-tectonic e.t.c. characteristics of the area.

Foreign and Greek Scientists have studied the complicated geological structure of Argolis Peninsula since the early of the $20^{\text {th }}$ century. Alpine and Post-Alpine Formations cover the Southern Argolis Penisnsula that are part of the following Geotectonic Units: Sub-Pelagonian (Papanikolaou, 1986, 
1989), Arvi-Miamou-Adheres (Papanikolaou, 1989) as well as Akros Unit (Baumgartner 1985, Papanikolaou et al., 1992) including the ophiolite nape of the Ocean Pindos-Cyclades. The formations of Argolis Peninsula are characterized by tectonic facies (thrusts and over-thrusts) of Upper Jurassic - Lower Cretaceus (Vrienlynck, 1978 a, b, 1980, Baumgartner, 1985) as well as Upper Eocene (Vrienlynck, 1978 a, b, 1980, Baumgartner, 1985, Gaitanakis and Photiades, 1989, 1991, 1993, Papanikolaou et al., 1992). Folds follow after thrusts and over-thrusts (Upper Eocene- Oligocene). The last tectonic facies of the region is the faulting tectonics of Neogene-Quaternary as well as the observed volcanicity of Saronikos Gulf (last $5 \mathrm{~m} . \mathrm{a})$.

\section{Methodology}

The used methodology in order to perform morpho-tectonic analysis in the Southern Argolis Peninsula will be presented. This work was made within the framework of a Doctorate thesis (Vassilopoulou, 1999), in the Department of Dynamic-Tectonic-Applied Geology, Faculty of Geology \& Geoenvironment, University of Athens. The aim of this thesis was to study the recent geodynamic evolution of the Southern Argolis Peninsula based on the terrain analysis by GIS development and the use of remote sensing data.

\subsection{Fieldwork}

The geological and tectonic data of the area were collected for the compilation of the "Synthetic Geological Map of Southern Argolis Peninsula", as well as "Tectonic map of Southern Argolis Peninsula". Fieldwork also included the checking of the maps of terrain analysis that were automatically produced by the "PROANA" software.

\subsection{GIS Development}

The GIS methodology was chosen, since there was a large number of data from various sources (thematic maps, satellite images etc.) in different forms (raster, vector) and in different map projections. ArcGIS package was used for the data processing, the map composition, the creation of the relational data-base and the data-base management.

\subsection{The Use of Remote Sensing Data}

Two digital satellite images LANDSAT 5, TM (16/8/91) and SPOT panchromatic (16/8/94) were processed. The Image Processing was made using the IMAGINE of ERDAS software package. This work can be divided in two steps:

- Image Pre-processing (Geometric Correction and Enhancement).

- Image Interpretation.

Additional processing has been applied to the LANDSAT image concerning the combination of spectral zones, as well as the principal components analysis. The main task was the image interpretation relating to the tectonic features (mainly faults and other tectonic contacts), geological and geomorphological features, based on the main diagnostic characteristics that are used from geo-scientists (Astaras, 1990, 1998, Migiros et al. 1995). The direct recognition of the tectonic features on satellite images, is based on the concept of morpho-structures and mainly on morpho-tectonics. Faults, joints and lineaments most likely have a rectilinear exposure on images and their determination depends on morphological features or in particular patterns. Gupta (1991) describes 
the criteria for the recognition of the faults. All the geological morphological and tectonic features were checked in the field and were imported to "PROANA" for the production of the corresponding maps and diagrams.

\subsection{The Development of the Specific Software "PROANA"}

The specifically developed software (based on ArcGIS), called "PROANA", was named after the Greek initials "Prototype Analysis Anaglyfou (Terrain)". All associated data and maps for the terrain analysis of Argolis Peninsula were automatically produced by "PROANA" (Vassilopoulou 1999, Vassilopoulou 2001). The geological and tectonic data were manipulated and the following maps were compiled (scale 1:50,000): "Synthetic Geological Map of Southern Argolis Peninsula" (Fig. 1a), "Tectonic Map of Southern Argolis Peninsula", "Tectonic Data from Satellite Images" (Fig. 1b). Terrain analysis layers, that have been produced by "PROANA", were related to the geological and tectonic layers, so that new synthetic layers and maps were compiled (scale 1:50,000) with their data base: "Digital Elevation Models (resolution 20m etc.)", "Shaded Relief”, "Map of Hydrographic Network and Basins", "Slope and Aspect Map", "Range map" (terrain is divided in categories of elevation zones), "Map of Discontinuities of Morphological Slopes", "Map of Terrain Analysis (Synthetic Map)" (Fig. 2c), "Map of Planation Surfaces Classified in Depositional and Erosional with theirs Slope Direction and Categorized with respect to their Slope" (Fig. 3d), "Planation Surfaces categorized related to their Elevation", etc.

\section{Geology and Tectonics}

A "Synthetic Geological Map of Southern Argolis Penisula" (Fig. 1a) is given by Vassilopoulou (1999). The following Post-Alpine and Alpine geological formations cover the region:

\section{Post-Alpine Formations:}

- Alluvial and Coastal Deposits (Quaternary): Unattached sands, clays, pebbles, breccias and gravels are observed. They are usually developed over the plains that are between the mountains or along water course, coastal areas, river mouth etc.

- Colluvial Deposits and Talus Cone: They consist of pebbles, breccias and congelifracts in different size, either cohesive and agglutinate or unattached. They mainly occur in water course mouth or along faulting zones etc.

- Porto-Cheli - Kranidi Conglomerates - Sandstones - Marls System (Plio-Pleistocene): The system covers the southern region of Argolis Peninsula and is overlaid on the "Kranidi Serpentinites" (in unconformity). It is characterized by small dip to the S-SW. Mainly calcareous but also serpentinites and psammitic pebbles consist the conglomerates. The matrix is calcareous or gridstone and pack sand as well as some times marly. Calcite dykes, calcite fragments and incrustations are observed. The system is overlaid on the lacustrine-terrestrial red pelitic fossil soil in several positions.

- Methana - Poros Volcanic Formations (Pleistocene): They consist of loose volcanic materials, pyroclastic deposits as well as concentrations of volcanic materials, domes and lava flows of dacides and andesites. They cover Methana Peninsula and the southern region of Poros Island.

Alpine Formations: They cover the rest of the region having the major extent. Two units can be distinguished: Argolis Upper Composite Unit which is in tectonic contact with Didyma Unit.

- Argolis Upper Composite Unit (synthetic upper tectonic unit of Southern Argolis Peninsula): 

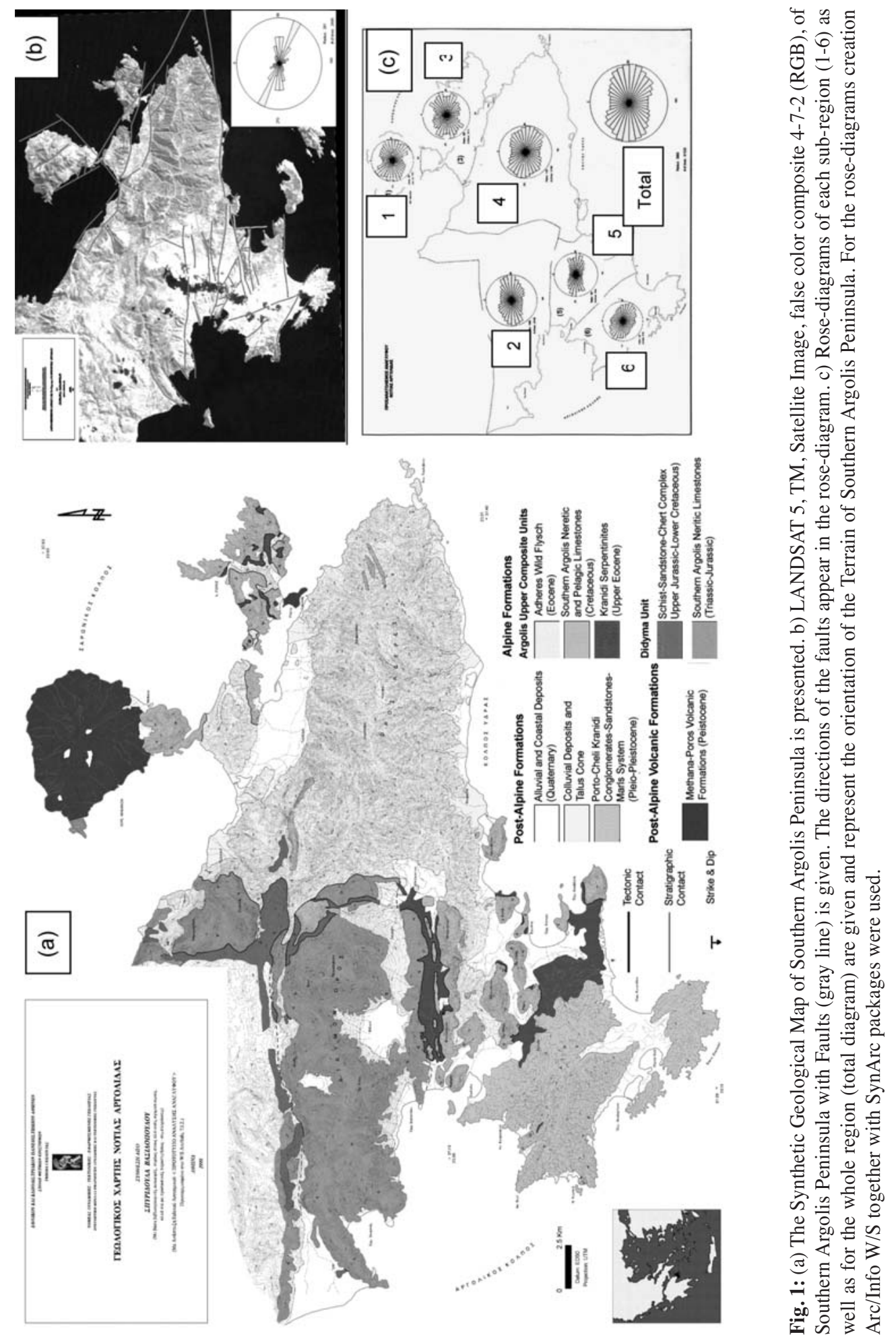

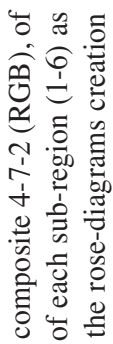
흥 है 兽 की ํำ 品哭 跑 证 i。 岕 更 Oิ 元 范 a

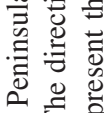
$\cong$

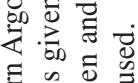
ข ठే

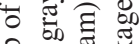

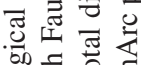
응 焉递 एँ $\frac{\pi}{3} \cdot \frac{5}{00}$ . $\Xi$

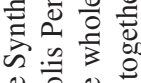
용

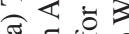

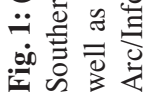
空. 
- Adheres Wild Flysch (Eocene): It belongs to Arvi-Miamou-Adheres Geotectonic Unit. Marls, calcareous-marly and turbidity sandstones, breccias and conglomerates compose the flysch.

- Southern Argolis Neritic and Pelagic Limestones (Cretaceous): Dolomites and quartz conglomerates occur in the base, while neritic, pelagic and intermediate limestones follow.

- Kranidi Serpentinites (Upper Eocene): It is an ophiolitic tectonic melange of serpentinites, hartzburgites, gabbros, amphinolites, andesitic lavas and marbles. This is the lower formation of the unit.

- Didyma Unit (Sub-Pelagonian - neritic basement):

- Schist-Sandstone-Chert Complex (Upper Jurassic - Lower Cretaceous): Schist-sandstone-chert complex with ophiolites are observed. This formation is in tectonic contact with "Southern Argolis Neritic Limestones".

- Southern Argolis Neritic Limestones (Triassic - Jurassic): Fine granular red limestones, neritic limestones of Pantokratoras and Ammonitico Rosso compose this formation.

The "Tectonic Map of Southern Argolis Peninsula" (Fig. 1b) is given by Vassilopoulou (1999). A Rose-diagram of the faults of the Southern Argolis Peninsula (Fig.1b) was created based on the thematic layer of the faults. The directions of the faults appear in the diagram.

\section{Terrain Analysis}

\subsection{Terrain Analysis of Sub-Regions of Southern Argolis Peninsula}

The relief of Southern Argolis Peninsula presents various structures. The region was divided in six sub-regions. The deviation of the region was based on the geomorphology, geology and tectonics. The six sub-regions were divided from North to South (Fig. 1c) as follows: (1) Region of Methana, (2) Region of Didyma - Iria, (3) Region of Southern Methana - Poros Island, (4) Region of Adheres, (5) Region of Kranidi-Ermioni, (6) Region of Porto-Cheli.

The qualitative and quantitative terrain analysis of each sub-region as well as of the whole region was based on the terrain analysis data (morphological slopes, morphological discontinuities, hydrographic network, planation surfaces - Figs 2c, 3d). The qualitative terrain analysis was done using the maps of terrain analysis relating to geology and tectonics (Figs 1a, b, 2c, 3d). The quantitative terrain analysis was based on terrain analysis layers, their database and the database management. The statistical analysis of the terrain includes the creation of a rose-diagram that represents the terrain orientation (Fig. 1c) together with diagrams that represent the mean elevation relating to percentage (\%) area of the study region (Fig. 2a), the mean elevation of planation surfaces relating to their percentage (\%) area (Fig. 3c), etc. A numerous of rose-diagrams for each sub-region and for the whole region (total diagrams) were produced representing the orientation of the linear structures of the terrain: morphological discontinuities, hydrographic network, watersheds (Figs 2b, 3a, b), etc.

The description of the morphological and tectonic features for each of sub-region follows:

(1) Region of Methana: The region includes Methana Peninsula, excluding the southern part of it. Interchanging hills and valleys are observed. The terrain is rough. It is a new structure since is covered from Pleistocene volcanic formations. Methana Peninsula consists the northern part of the Hellenic Volcanic Arc. This region is a neotectonic active block with N-S direction. NW-SE faults of West Saronikos Gulf are the boundaries of this block. The morphology, the structure and all the morphological features of the region, mainly depend on the volcano. 
(2) Region of Didyma - Iria: It extends along the north-western margin of the study area, between Argolikos Gulf (eastern) and Adheres Mountain (western). The terrain is characterized as rough (the "areal extend" is decreased when the altitude is increased). The region is covered from Alpine carbonate formations, mainly limestones of Sub-Pelagonian Unit. The fault-block has an E-W direction. It is observed that it is strongly uplifted compare to all the other blocks (planation surfaces are observed at an elevation of $1100 \mathrm{~m}$ ). The morphology of the region depends partially on tectonic activities and on lithology. At present time the erosion controls the terrain, apart from the coastal regions (near to Argolikos Gulf) that they are more active. The residuals planation surfaces, the morphological discontinuities the main branches of the hydrographic network, and the watersheds have a linear expansion in various parts of the region as it appears in the diagrams (Figs 2b, 3a, b). This direction corresponds with the alpine structures (tectonic contacts) and neotectonic structures (faults, etc). Cyclic features are also observed i.e. carbonate basins (Karst Doline of Didyma etc). Contrarily, Iria Plain (western), Loukaiti Plain (eastern) as well as other plains are not karstic and depend on tectonism since they correspond with E-W and NE-SW faults. E-W, NE-SW, NNW-SSE faults are observed while the rest of the tectonic contacts have E-W and N-S directions. The neotectonic fault-block seems to be a tectonic horst since the end of the Alpine Circle until today. Neogene sediments have not been observed. The general geometry of the tectonic structures is mainly according to the West Saronikos Gulf structures.

(3) Region of Southern Methana - Poros Island: The neotectonic fault-block extends at the southern of "Methana Region". It extends from the southern part of Methana Peninsula to the planation surface (southern) which is the northern boundary of Adheres and Poros Island. It is characterized by low elevations, excluding the Asprovouni Mountain (northern of Methana, 335m elevation) and Vigla Mountain (Poros Island, 358m elevation). The fault-block comprises Alpine formations (Eocene flysch, Cretaceous limestones, serpentinites- ultrabasic). The terrain is rough. Faults of EW and NW-SE directions are observed, while some of them are the boundaries of the region. Tectonism (mainly the tectonic structures of Saronikos Gulf) controls the block. Partially, NW-SE as well as E-W linear expansion of the features is distinguished. Some morphological features are not well formed, since faults with two directions control the terrain.

(4) Region of Adheres: The neotectonic fault-block includes Adheres Mountain (SE Argolis Peninsula) that has a great extent. Adheres Mountain extends in a direction E-W. High altitudes (500$700 \mathrm{~m}$ ) are observed on the ridge of the mountain. Eocene flysch covers the region with the occurrence of limestone rocks. The terrain is characterized by vertical dissection, a N-S dense hydrographic network and intense erosion. N-S linear expansion of the features is observed. The terrain is rough because of the existing steep slopes. The fault block is characterized as a tectonic horst related to Saronikos Gulf (on the North) and Hydra Gulf (on the South) that they are both tectonic grabens. The peculiarity of the relief mainly depends on the lithology since tectonic structures cannot be distinguished interiorly. E-W marginal faults on the North and South control the block and all the morphological features.

(5) Region of Kranidi-Ermioni: This neotectonic fault-block lies south to the "Didyma-Iria Region". Cretaceous limestones, serpentinites-ultrabasic rocks and flysch are observed. It extends from Hydra Gulf (east) to Argolikos Gulf (west) including the villages Fourni, Koilada, Kranidi, Alatovouni, Ermioni, Mouzaki to Petrothalassa (Kranidi Gulf). Small elevation hills are observed together with valleys. Mavrovouni (427m elevation), Profitis Elias (347m) and Asprovouni (396m) have the higher elevation. Alluvial cover the great coastal plains. Many E-W and NW-SE trending faults are observed which are distinguished clearly because of the occurrence of the fault surfaces, morpholog- 
ical discontinuities and other morphological and tectonic characteristics. The Fault-block is active and complicated with many faults dividing the region in smaller fault-blocks (horsts and grabens). The directions of the fault-blocks correspond to the directions of the faults. Generally, all the tectonic features are well developed. Linear structures are observed with a general E-W direction. The morphological features of the area as well as the creation of E-W and NW-SE horsts including limestones, grabens including serpentinites and flysch, but also alluvial basins depend on the tectonic activity.

(6) Region of Porto-Cheli: This region is the southern part of Argolis Peninsula. The terrain is hilly. Low and gentle morphological slopes are observed. This morphology is characteristic of the PostAlpine formations. Porto-Cheli-Kranidi Conglomerates - Sandstones - Marls System (Plio-Pleistocene) cover the region. The higher altitudes $(>200 \mathrm{~m})$ are observed to the north and the altitude decrease to the south. The main terrain orientation is WNW-ESE and a secondary N-S direction is observed. The main fault direction is NW-SE. Tectonism controls the terrain as well as all the morphological features. Plio-Pleistocene formations indicate that the region was recently under the sea level. At present time the region has been uplifted and some features have not been clearly formed in the region.

\subsection{Terrain Analysis of Southern Argolis Peninsula}

Southern Argolis Peninsula Terrain is characterized generally smooth, up to elevation of about $200 \mathrm{~m}$ (Fig. 2a). An anomaly is observed at the diagram of "mean elevation relating to percentage (\%) area", because of the "Doline Didyma". The terrain is rough from the elevation of $200 \mathrm{~m}$ to $700 \mathrm{~m}$ including some anomalies due to the occurrence of planation surfaces. The terrain is very rough from the elevation above of $700 \mathrm{~m}$, where high morphological slopes extend in small area.

\subsubsection{Planation Surfaces Classification}

The planation surfaces (slope 0-5\%) have been classified in four categories according to the diagram "the mean elevation of planation surfaces relating to their percentage (\%) area" (Fig. 3c):

a) Planation surfaces with low altitudes $0-30 \mathrm{~m}$ : They are mainly depositional (apart from the 3\% which are erosional) covering the $38 \%$ of the total area of all the planation surfaces. They are developed over all the formations of the region. They are coastal having large extent and they are related to the neotectonic faults (Fig. 3c,d).

b) Planation surfaces with altitudes 170-210m: They are mainly depositional covering the $9 \%$ of the total area of all the planation surfaces. They are developed over the limestones of Didyma Unit (Didyma-Iria Region) having large extent (but smaller than the previous category). Some of them (having small extent) are developed over flysch (Fig. 3c,d).

c) Planation surfaces with altitudes $70-110 \mathrm{~m}$ : They are erosional covering the $3 \%$ of the total area of all the planation surfaces (Fig. 3c,d). They are mainly developed over the Post-Alpine formations (Porto-Cheli Region). Few planation surfaces are developed over serpentinites and ultrabasic rocks (Ermioni-Kranidi Region).

d) Planation surfaces with altitudes 350-390m: They are depositional and erosional having the $1 \%$ extent of the total area of all the planation surfaces (Fig. 3c,d). This category represents mainly the "Doline Malavria" (Didyma-Iria Region) which has been recently created, and the northern boundary of the region, which is covered from schist-sandstone-chert complex (western of Ortholithi). 
The rest of the planation surfaces (erosional and depositional) have very small percentage of the total area of all the planation surfaces and extend in a very small area.

The planation surfaces (slope 5-15\%) are mainly developed over the Post-Alpine formations having large extent. They have smaller surface extent when they are developed over the talus slope (Didyma Unit). The rest of the planation surfaces cover very small area.

\subsubsection{Terrain Orientation}

$\mathrm{E}-\mathrm{W}$ is the main terrain orientation as appears in the rose-diagram (Fig. 1c), while all the other directions are represented with smaller rates to the rose-diagram (Fig. 1c). The N-S direction represents the smaller rate in the diagram.

\subsubsection{Morphological Features and Faulting Zones Direction}

$\mathrm{E}-\mathrm{W}$ is the main direction of the morphological discontinuities. The NE-SW direction and the N-S direction have smaller rate of appearance in the rose-diagram (Fig. 2b). Additional, all other directions have also small rates (Fig. 2b).

The hydrographic network has mainly NW-SE direction, and in some areas the directions changes to N-S and E-W. All other directions appear in the diagram with smaller rates (Fig. 3a).

ENE-WSW is the main direction of the watersheds while the N-S direction represents smaller rate in the diagram. All other directions appear in the diagram with smaller rates (Fig. 3b).

The direction of the Faulting Zones is mainly WNW-ESE and E-W. The NW-SE direction and the NE-SW have smaller rates (Fig. 1b).

\section{Conclusions}

Ground and remote sensing data relating to geology and tectonics were compiled with terrain analysis data (automatically produced by the "PROANA" software) in a GIS data base to perform morpho-tectonic analysis in the Southern Argolis Peninsula.

From "Didyma-Iria" fault-block (North) to "Porto-Cheli" (South), the neotectonic deformation increases. This is expressed by the increase of the morpho-tectonic and tectonic features (planation surfaces, morphological discontinuities, faults) which are more evident at the southern. Also, the faults are related to intense morphological discontinuities, while the faults-mirror, the fault breccia and other tectonic characteristics, are greater in number and clear.

Summarizing, the most active tectonic structures are observed to the southern and south-western area of Southern Argolis Peninsula, towards Kranidi and Argolikos Gulf.

Apart from the general E-W direction of the structures a NW-SE direction is also observed from North to South. The latter happens since the Southern Argolis Peninsula is in between West Saronikos Gulf, which is characterized mainly by E-W faults, and Argolikos Gulf which is characterized by NW-SE faults.

"PROANA" software can be used as a useful tool for various environmental applications, related to the terrain analysis. 

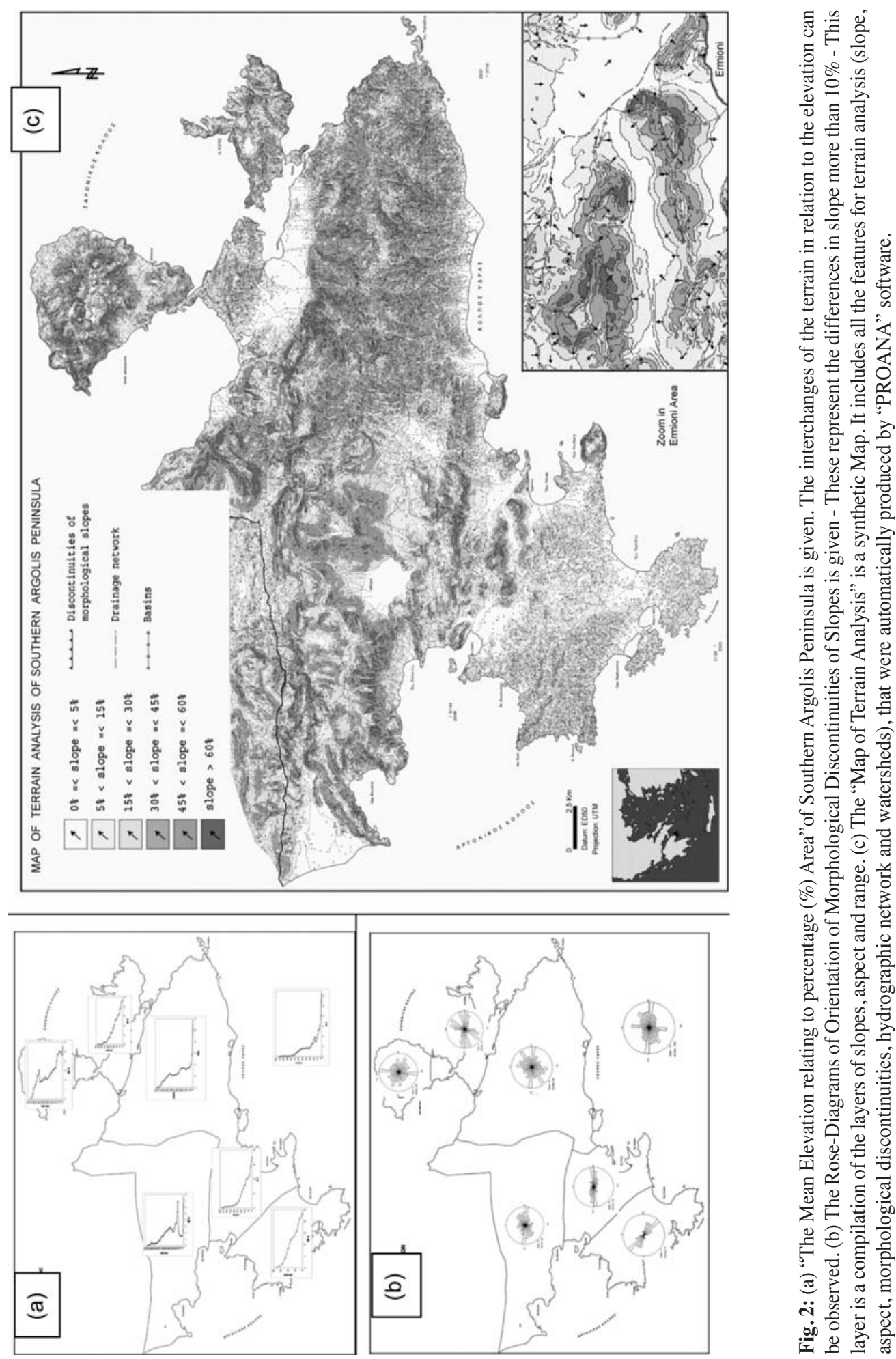


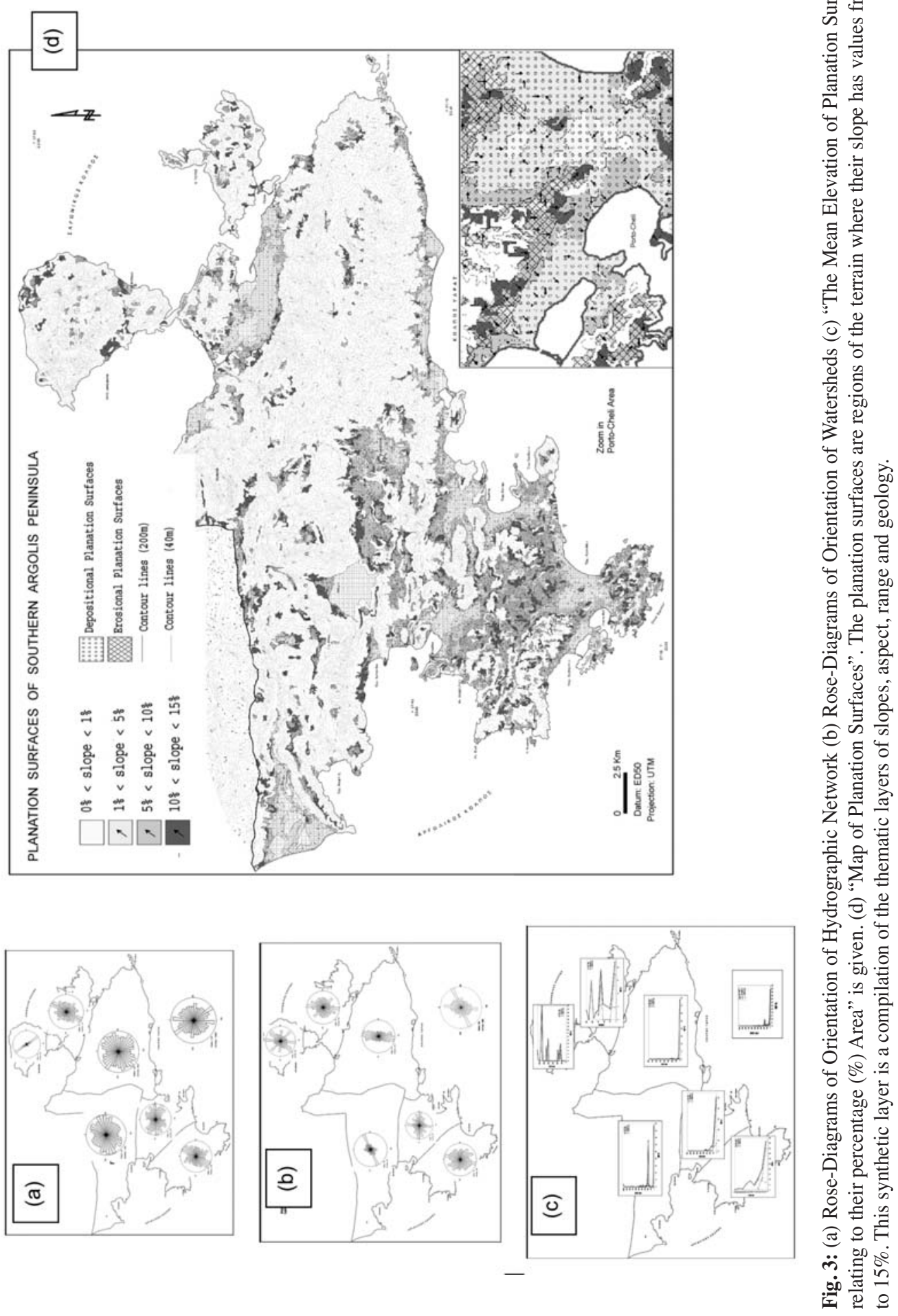




\section{Acknowledgments}

The author would like to thank Prof. D. Papanikolaou, Prof. E. Lagios, Prof. E. Lekkas, Pof. L. Hurni (ETH, Zurich), Prof. Ch. Metaxaki, E. Andoniou, Ass. Prof. S. Lozios, Ass. Prof. Is. Parcharidis, Dr. V. Sakkas and one anonymous referee for their useful comments, as well as MDS Marathon Data Systems Company for their help with ArcGIS s/w package.

\section{References}

Astaras, Th., 1990. The contribution of Landsat Thematic Mapper Imagery to the Geological and Geomorphological Reconnaissance Mapping in the Mountain Area of Kerkini - SW Part of Rhodope Massif and the Surrounding Plains (Hellenic - Boulgarian Borders). Geographica Rhodopica, vol. 2, p.105-114.

Astaras, Th., 1998. Photo-Inerpretation (Remote Sensing) in Geosciences. Notes, Aristotle Univ. of Thessaloniki, School of Geology, Dep. of Geology and Phys. Geography.

Baumgartner, P.O., 1985. Jurassic Sedimentary Evolution and Nappe Emplacement in the Argolis Peninsula (Peloponnesus, Greece). Univ. Basel. 137p.

Gaitanakis, P., Photiades, A.D., 1989. Les Unites Ophiolitiques de l' Argolide (Peloponnese, Greece). Bull. Geol. Soc. Greece, XXIII /1, 363-380, Athens.

Gaitanakis, P., Photiades, A.D., 1991. Geological Structure of Southern Argolis. Bull. Geol. Soc. Greece, XXV /1, 319-338, Athens.

Gaitanakis, P., Photiades, A.D., 1993. New Data on the Geology of Southern Argolis (Peloponnesus, Greece) Bull. Geol. Soc. Greece, XXVIII /1, 247-267, Athens.

Gupta, P.R., 1991. Remote Sensing in Geology. Springer-Verlag, 356.

Migiros, G., Pavlopoulos, A., Parcharides, Is., 1995. Remote Sensing - Applications in Geosciences. Notes, Agricultural Univ. of Athens, Labor. of Oryctology-Geology, Athens.

Papanikolaou, D., 1986. Geology of Greece, p. 240, Athens.

Papanikolaou, D., 1989. Geotectonic map of Greece. Geol. Soc. Of Greece, Spec. Publ. No 1, IGCP Proj. No 276, Newsletter No 1.

Papanikolaou, D., Lekkas, E. Logos, E., Lozios, S., 1992. Neotectonic Map of Greece (Lygourion Sheet), Research Project, Nomarchy of Argolis.

Vrielynck, B., 1978a. Donnees nouvelles sur les zones internes du Peloponnese, Grece. Diss. Univ. des Sciences et Techniques Lille, These $3^{\circ}$ Cycle, $134 \mathrm{p}$.

Vrielynck, B., 1978b. Donnees nouvelles sur les zones internes du Peloponnese. Les massifs a l' est de la plaine d'Argos (Grece). Ann. Geol. Pays Hellen., 29, 1977, 440-462, Athenes.

Vrielynck, B., 1980. Les tectoniques tangetielles des zones internes du Peloponnese (Argolide, Grece). C.R. Acad. Sci. (Paris) 290, Serie D, 967-970.

Vassilopoulou, S., 1999. Geodynamics of the Argolis Peninsula with GIS development and the use of Remote Sensing Data. PhD Thesis, University of Athens, Faculty of Geology, p. 194.

Vassilopoulou, S., 2001. "PROANA” A Useful Software for Terrain Analysis and Geoenvironmental Applications - Study Case on the Geodynamic Evolution of Argolis Peninsula, Greece. Proc. $20^{\text {th }}$ International Cartographic Conference, Beijing, China, pp. 3432-344. 